\title{
7 \\ Native land policy in the 2014 elections
}

\section{Sefanaia Sakai}

\section{Introduction}

One of the most debated issues prior to the September 2014 elections in Fiji was the security of Taukei land. This resulted from uncertainty about the implications of the many changes the Bainimarama Government had introduced since it took control of the government after the 2006 coup. In response, the political parties included policies on land issues in their manifestos. This chapter begins by examining the way in which land issues were addressed by the two major parties: the Social Democratic Liberal Party (SODELPA) and the FijiFirst Party. SODELPA promised to roll back Bainimarama's reforms, while FijiFirst proposed to further improve access to and utilisation of native land. The other political parties adopted a moderate position on land in the hope that the contradictory views espoused by the two major parties would be to their advantage. The chapter aims to analyse the extent to which the land issue, and the rhetoric of the leading parties, was a factor in the election result. 


\section{The 2014 general elections}

After eight years of political uncertainty, the 2014 September elections restored democratic rule in Fiji, much to the relief of the people of Fiji as well as others in the region. Despite some criticisms, ${ }^{1}$ the elections were labelled as free and fair by the Multinational Observer Group (MOG). FijiFirst won a landslide victory, polling 59.2 per cent of the total votes, dispelling any hope of a coalition government expected by some political analysts. The voting age was reduced from 21 to 18 years, and 84.6 per cent of Fiji's 591,101 registered voters participated in the 2014 general elections (Fijian Elections Office 2014).

There had been much speculation by various observers about the possible outcome of the elections, although former vice president and high court judge Ratu Joni Madraiwiwi noted the difficulty of knowing what voters were actually thinking ahead of the polls. The fact that the elections were being held under a new constitution, and with new parties competing for the first time, together with the fact that it had been eight years since the last elections, made it almost impossible to use past trends as a basis for judging the outcome in September 2014. Even so, land had been a particularly sensitive issue in all elections since independence in 1970, and it was reasonable to expect that the radical changes made to Taukei land policy under the Bainimarama regime prior to the elections might result in a backlash against FijiFirst among Taukei voters, with SODELPA as the main beneficiary. SODELPA certainly promoted the view that the changes to native land laws would bring social, economic and cultural disaster to the Taukei.

At least part of the problem surrounding the election hype over land issues was due to ignorance on the part of Taukei landowners regarding their legal rights, which made them easy prey to fearmongering propaganda, as had occurred in previous elections. As Lal (1988, p. 81) noted, the Alliance Party, which had formed the government in Fiji since independence, exploited 'the land fear strategy' against the newly formed Fiji Labour Party in the 1987 general elections.

1 See 2014 Electoral Commission Report. One of its recommendations concerns the need for changes to relevant sections of the 2013 Constitution, the Electoral Decree and the Political Parties Decree to allow good governance in the election process. 


\section{Chiefs, custom and land}

Official records show the Taukei owned about 91 per cent of the land while freehold and crown land made up approximately 6 and 3 per cent of the remaining land respectively (TLTB 2014, p.8). A significant difference between customary Taukei land tenure compared to western systems is its communal ownership, which is held in accordance with customs and traditions. Individual Taukei do not have legal title to native land but each individual is registered under a mataqali (clan) which is the legal land owning unit, as stated in the Native Land Act 1961. The mataqali can neither sell land to outsiders nor grant private property rights to individual members. In practice, each mataqali is entitled to a share of the land that constitutes the vanua or village. In pre-contact time, however, all land belonged to groups of Taukei, although land tenure systems varied throughout the islands. The Tukutuku Raraba $a^{2}$ recorded by various Native Land Commissions (NLCs) demonstrated that precolonial customs were far from homogeneous. Various groups of Taukei were frequently displaced, their composition was fluid, and hierarchy varied considerably by region (France 1969; Nayacakalou 1975; Ravuvu 1998).

Customary views on land transcend the tangible representation of resources. This contributed to the Taukei's resolve to protect their land from alienation. Like other Taukei scholars, Tuwere (2002, p. 36) reaffirms that for Taukei, land, spirit and people are integral to the vanua, ${ }^{3}$ and the components are inseparable. Thus the vanua is seen as a 'social fact' that holds the Taukei together and gives it meaning (Tuwere 2002). This view incorporates a host of spiritual values as well as more practical aspects of land ownership and use. In earlier periods, the idea of a sacred tie was often emphasised by the spokesmen representing their vanua when giving evidence to the Native Land Commission (NLC) on landownership and occupation (France 1969, p. 10). Narration would include tribal origins linked to a known god in a given area. Consequently, Taukei land tenure practices were

2 Oral traditions of the landowning units and individuals regarding historical accounts such as initial land settlement, ownership, distribution and occupation.

3 The vanua, for Taukei, literally means 'land', but it encompasses a holistic meaning attached to it which includes the Taukeis' identity, resources, culture and spiritual being. 
formulated in what Malinowski referred to as 'codification of belief' (cited in France 1969, p. 10). It is because of the strength of this value system that land is not seen as a commodity (Boydell 2005).

Although traditional land tenure systems were varied and flexible, colonial order required a certain uniformity throughout the islands and so Sir Arthur Gordon, the first colonial governor, instituted a formal native land tenure system that could be applied in all parts of the island group. In addition to introducing a certain degree of uniformity where it had not previously existed, the system was designed to protect indigenous land and the way of life from the greed of white settlers (France 1969, p. 107). However, some scholars have argued, and rightly so, that the colonial policy of protecting Taukei also impeded their socioeconomic progress (Boydell 2005; Lawson 1996; Nayacakalou 1975).

Another important point to note is that although Taukei land was protected, the need to develop a plantation economy required some flexibility, some modifications in the system, and so the leasing of native land for agricultural purposes was introduced. In 1936, Ratu Sir Lala Sukuna, the first indigenous Native Land Commissioner, together with the Great Council of Chiefs (GCC) determined that all land not required for the sustenance of Fijian owners was to be made available for national development through native land leases. A Native Land Trust Board (NLTB) was established in 1940 to administer and protect native land. In the process, chiefs recommended to the colonial administration that land policies not only safeguarded land ownership but also secured their positions in a changing society. As a result, chiefly control became an integral part of the colonial native land tenure system, which included the distribution of wealth from land development.

Fijian chiefs, who were regarded as anointed by God, obviously occupied a special position in traditional Fijian society, being given precedence, loyalty, obedience, authority, privilege and respect (Nayacakalou 1975, p. 81). But their primary role was to look after the welfare of the people and to safeguard resources and ensure distribution, such that every member of the group had access to land. Surprisingly, historical records show that prominent chiefs actually sold large areas of land, thereby contravening their traditional roles as custodians of ancestral land. For instance, Derrick (1968, p. 185) 
writes that in Vanua Levu, the second largest island of the Fiji group, land sales were assumed to be the prerogative of the high chiefs and few dared to question them.

As with the land tenure system, the role of chiefly authority was reconfigured and codified by the colonial government. Under the separate Fijian Affairs Board, Taukei were made to live as a communal group under traditional leaders whose privileges and status were increased and secured, while the land rights of individuals and small groups were submerged in mataqali groups, restricting the free transfer of land between groups and individual in times of need (Tupouniua, Crocombe \& Slatter 1980, p. 33). Ravuvu (1998, p. 129) explains that land which was once considered by the people of the village to provide them with various needs for their daily lives had been made sole property of a particular mataqali. The method of allocating land rights introduced by the colonial government were, as noted above, much more rigid and as a consequence often failed to meet the needs of village life (Ravuvu 1998).

As for the high chiefs, their positions were firmly entrenched during colonial rule through the Native Regulations. This was very unlike precontact times, when inefficient leaders could be wiped out by stronger and more efficient leaders, especially during tribal wars (Tupouniua, Crocombe \& Slatter 1980, p. 33). Consequently, Fijian individuality was suppressed under many self-serving traditional leaders whose claim to office rested on nothing more than the accident of birth. Any attempt to break away from this bondage was firmly suppressed under the new powers given to chiefs under the Native Regulations.

Fiji's history also shows lack of commitment by Taukei political leaders to implement positive legislative changes to meet the changing needs of society. Nayacakalou (1975, p. 5) discussed the dilemma facing Fijian leaders regarding the preservation of Fijian culture, including the system of land tenure and management. If any advocated radical change they could attract accusations of being anti-Taukei; on the other hand, if they emphasised the importance of maintaining traditional (or neo-traditional) ways, they were accused of being reactionary.

This dilemma remained a serious problem in the post-independence period, especially whenever issues concerning Indo-Fijian farmers and their need for secure leases were raised. The chiefs represented 
themselves as the only ones capable of ensuring that Indo-Fijians did not take over Taukei land altogether, although this was never a real possibility, either legally or politically. This was in addition to the constant emphasis on the notion that there is a sacred, unbreakable connection between land, chiefs and the vanua. These notions were featured prominently in post-independence election rhetoric aimed at Taukei voters. In the 1987 elections, for instance, a prominent Alliance politician of chiefly status blamed the Labour-National Federation Party coalition for trying to meddle with the scared ties between the turaga (chiefs) and the vanua. A warning was issued concerning the dire consequences for the future of Taukei (Lawson 1996, p. 50). One chief stated that 'the Turaga and the Vanua were one - one could not exist without the other - the chiefs were a bulwark of security for all and the custodians of Taukei identity, land and culture' (Lawson 1996).

The political triumphs and failures of the architect of the 1987 coups, Lieutenant-Colonel Sitiveni Rabuka, were tied to how Taukei regarded him as protector of Taukei interests, including land. In the aftermath of the 1987 coups, he was seen as the champion of Taukei rights in the face of alleged threats to land, identity and the entire edifice of Taukei tradition (Lal 2000; Lawson 1996). But this was to change when Fiji returned to democratic rule. Lal (2000, p. 326) notes that when Rabuka's Soqosoqo ni Vakavulewa ni Taukei (SVT) party went into coalition with the largely Fiji-Indian National Federation Party to form a coalition prior to the 1999 general elections, many Taukei voters deserted him and his party because he was seen as betraying Taukei interests and Taukei political control.

With respect to the 2000 coup, Boydell's (2005) analysis suggests that one reason for the 2000 civilian coup was a growing concern among Taukei about land security under the Chaudhry Government, especially when it appeared that the government wanted to legislate to allow access to unused native land for development without considering the welfare of Taukei landowners. With these factors in mind, the issue of Taukei insecurity (whether based on real threats or fabrications) needs careful analysis and understanding, especially by non-Taukei, for many Taukei will view them with suspicion in matters concerning land. 


\section{Land security issues in the 2014 elections}

Given this background, it is no surprise that the issue of land was one of the most contested campaign issues prior to the 2014 elections, as evident in the party manifestos, opinion polls, policies and land decrees. The SODELPA and FijiFirst manifestos, as set out in Table 1, reflect contrasting positions on land protection and land innovation, although both claimed to be advocating both objectives.

Table 1: SODELPA and FijiFirst manifestos on native land

\begin{tabular}{|c|c|c|}
\hline & SODELPA & FijiFirst \\
\hline Land Policies & $\begin{array}{l}\text { Uphold Native Land Act } 1997 \\
\text { Constitution entrenchment provision } \\
\text { on Native Land Act. Revise the } \\
\text { equal distribution policy. Abolish } \\
\text { the Land Use Decree. Revise the } \\
\text { Surfing Decree. Land protection as } \\
\text { in the } 1997 \text { Constitution. }\end{array}$ & $\begin{array}{l}\text { Uphold Native Land Act } 2013 \\
\text { Constitution. Continue with Land Use } \\
\text { Decree and equal distribution policy. } \\
\text { Uphold the Surfing Decree. Land } \\
\text { Protection as in the } 2013 \text { Constitution. } \\
\text { FJD\$10 million to help Land Owning } \\
\text { Unit (LOU) develop land. }\end{array}$ \\
\hline $\begin{array}{l}\text { Great Council } \\
\text { of Chiefs }\end{array}$ & Re-establish the GCC. & Abolish the GCC \\
\hline Secular State & $\begin{array}{l}\text { Secular state gives lesser value } \\
\text { towards Christian role in Fiji. }\end{array}$ & $\begin{array}{l}\text { Support secular state as part of } \\
\text { equal citizenship. }\end{array}$ \\
\hline Constitution & $\begin{array}{l}\text { Revise } 2013 \text { Constitution with } \\
\text { inclusion of the } 1997 \text { Constitution. }\end{array}$ & Uphold the 2013 Constitution. \\
\hline $\begin{array}{l}\text { iTaukei Land } \\
\text { Trust Board }\end{array}$ & $\begin{array}{l}\text { Restructure and keep as the } \\
\text { legal custodian of native land as } \\
\text { institution. }\end{array}$ & $\begin{array}{l}\text { Restructure and drive for economic } \\
\text { development for the betterment of } \\
\text { iTaukei and Fiji. }\end{array}$ \\
\hline $\begin{array}{l}\text { Squatter } \\
\text { Settlements }\end{array}$ & Provide affordable housing. & $\begin{array}{l}\text { Squatters on native land given } \\
\text { residential 99-year leases with LOU } \\
\text { approval. }\end{array}$ \\
\hline
\end{tabular}

Source: Derived from the manifestos of SODELPA and FijiFirst, 2014.

On land policy, SODELPA promised to facilitate consultation regarding the 2010 Leases and Licences Regulations amendment and to immediately abolish the 2010 Land Use Decree if elected to government. It also said it would uphold the ILO (International Labor Organization) Convention 169 and the 2007 UN Declaration on the Rights of Indigenous Peoples ${ }^{4}$ to strengthen opposition to the 2013 Constitution.

4 This declaration, while accepting the fundamental equality of all peoples, nevertheles notes that many indigenous peoples the world over have suffered marginalisation through colonialism, and recognises the need to respect and promote the rights of indigenous peoples affirmed in historical treaties and other agreements with the state. 
FijiFirst's manifesto built on their existing policies, which they claimed fostered inclusive growth for all Fijians. As for land issues, the party pledged to uphold the Land Use Decree and provide financial support for Land Owning Units (LOUs) who wished to develop their land. Additionally, they promised to provide a 99-year residential lease to squatters residing on native land with the approval of LOUs. Other parties such as the National Federation Party (NFP) ${ }^{5}$ and the People's Democratic Party (PDP) adopted a balanced approach regarding changes to native land legislations, arguing that proper mechanisms should be followed and native land ownership should be protected. The NFP for instance, pledged to include the entrenchment clause in the 2013 Constitution for native land legislation and would not exercise the power of 'compulsory acquisition' of native land as stated under Section 27 of the 2013 Constitution (NFP 2014, p. 19). The party clearly supported SODELPA's stance that land issues and Taukei institutions needed wider consultation rather than the nonconsultative approach taken by the regime.

The Tebbutt opinion poll in August 2014 showed that 74 per cent and 16 per cent of registered voters considered land issues as very important and quite important respectively. ${ }^{6}$ This was across all age groups, both genders and all ethnicities in both the Central and Western divisions of Fiji. Interestingly, only 25 per cent said they understood land issues quite well, while 83 per cent said they would like to know more about the subject (Vakacolo 2014). As noted above, native land protection is extremely important for indigenous people for a variety of reasons; not least, because in a competitive world it is the only resource that provides a sense of social, political and economic security. However, Taukei land rights are in fact protected under the 2013 Constitution as well as under two sets of native land legislation introduced by the Bainimarama regime in 2010. These will now be examined in greater detail.

5 The National Federation Party is the longest-surviving Indo-Fijian dominant party since independence and, like SODELPA, would adopt a consultative approach regarding land issues and reinstatement of the GCC if it won the elections.

6 Tebutt poll conducted on 1,047 registered voters between 4 and 6 August. The poll asked: 'How important is the land ownership issue to the nation? How well would you say that you understand the current land ownership issues that are being discussed? And how interested are you to learn more about land ownership issues?' 
In 2010, the Bainimarama Government amended the Leases and Licenses Regulations of the Native Land Act to ensure equal distribution of lease money to mataqali members. The amendment was introduced in line with a government policy of inclusiveness and designed to address inequality among Taukei landowners. Wealth from the use of Taukei land through leasing has been substantial, but had not been distributed on an equal basis. According to the iTaukei Land Trust Board (TLTB, formerly the Native Land Trust Board or NLTB), the total lease income distributed to LOUs has increased from FJD\$24 million in 2000 to FJD\$64 million in 2014 (TLTB 2014, p. 11). For the first time, under the new equal distribution policy, chiefs and commoners within a mataqali would share the economic gains from the use of their mataqali land equally (see hypothetical scenario Figure 1). Before the amendment, the TLTB usually deducted 25 per cent as an administration fee and also to assist the TLTB to generate development projects on Taukei land. There were also three categories of chiefs who received the largest share of the lease money under the old distribution system: turaga ni vanua (village chief) received 5 per cent, turaga ni yavusa (tribal chief) received 10 per cent, and turaga ni mataqali (clan chief) received 15 per cent. Often a single chief would receive the full 30 per cent entitlement because he was holder of all three titles and belonged to the clan whose land was leased for development. The remaining 45 per cent was shared by the rest of the mataqali members. In 2013, the Bainimarama regime also reduced the TLTB share from 25 per cent to 10 per cent, putting an emphasis on the TLTB self-funding its own operation rather than relying so heavily on deductions from lease money.

The equal distribution policy has also contributed to the reduction in the number of registered disputes over chiefly titles in the country in 2013 and 2014. For example, the Native Lands Commission received three chiefly titles dispute cases in 2014 compared to 13 recorded cases in 2013. The commissioner attributed this decline to the implementation of the equal distribution policy by the Bainimarama Government (FBC 2014). However, the validity of this analysis could be substantiated only after in-depth research on the issue of equal distribution and titles disputes. 


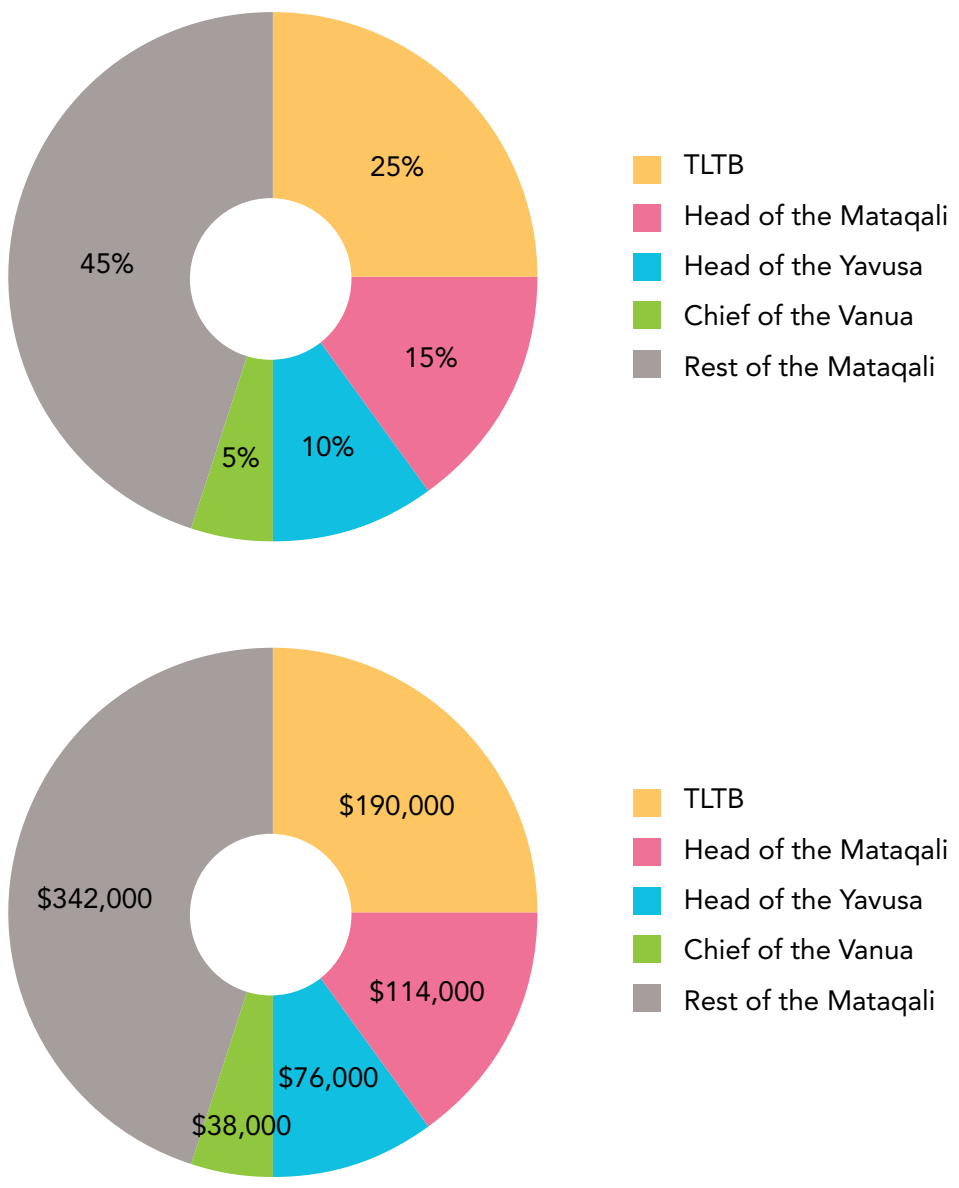

Figure 1: Old distribution policy FJD\$760,000: A hypothetical scenario

Source: Sakai 2014, presentation at Tahiti PIPSA conference.

Returning now to the responses by political parties: SODELPA portrayed these reforms as detrimental to the livelihoods of Taukei and a violation of indigenous rights. From the outset, it must be noted that SODELPA had attempted to use land security issues and also the abolition of the GCC in 2012 (through the Taukei Affairs Revocation Regulation), which put an end to the GCC's 136 years of existence, as a trump card to attract Taukei voters in its 2014 election campaign (Fraenkel 2014, p. 2). Bainimarama had questioned the GCC's relevance to the country's contemporary political structure and criticised the institution as being not only highly politicised but 
also irrelevant in an era that championed the equality of Fiji's citizens (Gonedua 2012). Another issue for SODELPA was the ban placed on the Methodist Church's annual national conference under the Public Emergency Regulations. SODELPA, in opposing the restrictions on church activities, attempted to appeal to the largely Methodist Taukei voters. Indeed, many Methodist Church followers had previously formed a substantial part of the support base of SODELPA's immediate predecessor, the Soqosoqo Duavata ni Lewenivanua (SDL) party, which had been overthrown while in government in 2006 (see Newland, this volume). Finally, in early 2013 the Bainimarama Government withdrew all ethnic-based scholarships, including the Fijian Affairs Scholarship, which had served to promote education for Taukei students at the expense of other ethnic groups.

With respect to land policy, SODELPA claimed that the equal distribution of lease monies was not conducive to the traditional livelihood of Taukei. SODELPA leader Ro Teimumu Kepa, a high chief and beneficiary of the previous system of distribution, explained that chiefs, as heads of the mataqali and yavusa, had responsibilities to the vanua and their larger shares would cater for major obligations. Deposed SDL Prime Minister Laisenia Qarase, while campaigning for SODELPA, invented his own version of redistribution when replying to a question that the author posed during the SODELPA campaign in Wainivula, Suva. He said that the party would let the provincial council decide on the fate of the equal distribution policy in consultation with the people. This was clearly different from Ro Teimumu's position that SODELPA would revert to the old system.

These contradictory views became counterproductive to the party's campaign before the elections. ${ }^{7}$ First, in advocating the old distribution system, Ro Teimumu was condoning inequality among Taukei, using facile cultural justification. What the party overlooked was that many chiefs in Fiji did not receive lease money yet still fulfilled their obligations to the vanua successfully because communalism and reciprocity were crucial values of Taukei culture.

7 SODELPA, through Qarase, had given a few contradictory views such as on land and the interpretation of the secular state during the 2014 election campaign, which may have dissuaded people from voting for the party. 
The old distribution policy actually contributed to inequality and the marginalisation of ordinary Taukei in their traditional villages; and they never questioned it because of the belief that it was an essential part of Taukei culture. It must be noted that the chief's lease allocation was a private entitlement and he was not obliged by law to spend or redistribute his share of lease monies on traditional obligations. Those chiefs in receipt of land monies had benefited from a land policy that had its origins in the colonial order, which contributed to some chiefs becoming individualistic and very wealthy while ordinary Taukei remained disadvantaged despite also being owners of an important communal resource.

In advocating a policy of equal citizenship, Bainimarama criticised the chiefly institution as promoting inequality amongst the Taukei community by holding on to privileges bestowed, not by tradition, but by colonial laws. In the past several decades, neither the GCC nor political leaders had taken any steps to reform land policies to benefit all Taukei. Despite promises by previous Taukei-led governments such as the SVT and SDL to improve Taukei welfare, the socioeconomic situation of most Taukei continued to deteriorate. ${ }^{8}$ Narsey (2008, p. vii) suggests that the proportion of Taukei living in poverty in 2000 was about 49 per cent in early 2000, although that could have increased after the 2006 coup because of the initial economic downturn.

It can be argued that to change something that benefits the majority of Taukei landowners through fair distribution would be unethical. In the hypothetical scenario illustrated in Figure 2, for instance, under the equal distribution policy, the FJD $\$ 760,000$ revenue from the leased land is distributed to two recipient groups, the TLTB (FJD\$76,000) and mataqali (FJD\$684,000), with the latter figure being distributed equally to all members. Thus if the mataqali has 300 members, each one will receive FJD $\$ 2,280$, including women and children. It is then the prerogative of the landowners to decide what to do with the income. For instance, even with the new policy in place, some landowning units may have a consensual agreement that the heads of vanua, mataqali and tokatoka continue to receive their normal shares, or at least a higher proportion than other mataqali members, as a reward for good leadership prior to the amendment. However, governance at 
village level is not necessarily inclusive and the consensus reached may not take into account the views of women and youth, who usually remain silent in community discussions.

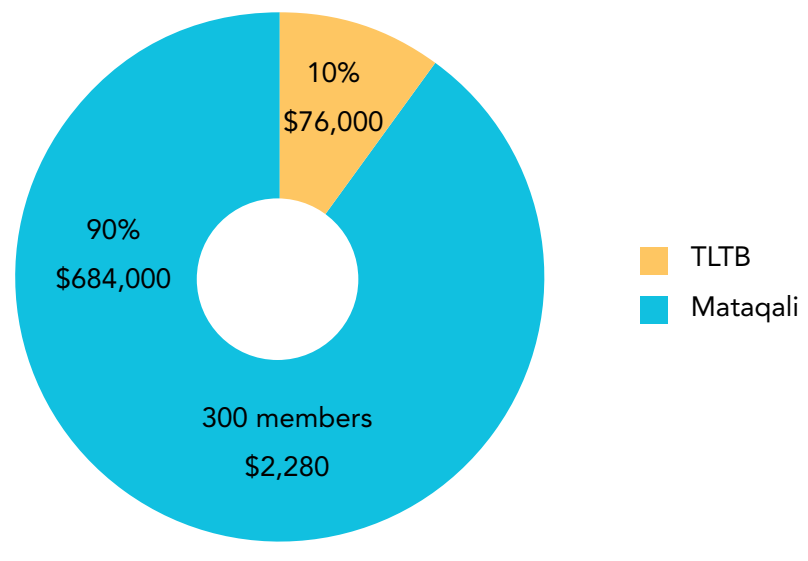

Figure 2: New equal distribution share FJD\$760,000: A hypothetical scenario

Source: Sakai 2014, presentation at the Tahiti PIPSA conference.

Following the reforms, there has been no major resistance to the changes made by the Banimarama government, except from SODELPA. However, silence on these matters does not mean acceptance of the policy changes. Many Taukei feel constrained in articulating their views publicly on many political issues for cultural reasons (Madraiwiwi 2014; Nabobo et al. 2005). While silence is part of custom, Taukei support for the interim government may have also contributed to a subdued response.

Another contested issue prior to the elections was the 2010 Land Use Decree, a policy framework that aims to facilitate productivity of unused native and crown land. Under the decree, unused native land would be deposited in a Land Bank provided that 60 per cent of the mataqali members consent. Once the land is designated and deposited, the government would find potential investors who would be sub-lessees and would develop the land according to the provisions of the lease agreement. SODELPA had publicly campaigned against the decree, arguing once again that it would erode Taukei rights. SODELPA pointed out that there was one clause in the decree that removed the right of native land owners to seek redress in a court or 
tribunal. The party had mainly used a Fiji-based study and its own legal expertise to highlight the weaknesses of the decree. This study (see Dodd 2012) provided a detailed analysis of the legal implications of allocating Taukei land under the Land Use Unit, which included unchallenged legal power allocated to government to control native land for the duration of lease. ${ }^{9}$ It is argued that the Land Use Decree would weaken the LOU's decision-making process and disputesettlement capacity once the land was designated and the negotiation grace period of five years had lapsed, giving the government and investors total control of native land.

In its media release on the issue, SODELPA noted its reservations regarding the process of achieving majority consent and the confusion between individual rights and group rights regarding native land protection under the Land Use Decree. ${ }^{10}$ The party also noted that the decree did not protect Taukei land from alienation as in other past constitutions and its real intention was to allow foreign investors easy access to native land on 99-year lease terms, and this effectively alienated the land for up to four generations.

In paving the way for this decree one necessary step had been the abrogation of the 1997 Constitution, which allowed the Bainimarama regime to abolish the GCC. Under the 1997 Constitution, the GCC had constitutional power to stop any amendments regarding any parliamentary proposal that might lead to possible alienation of Taukei land. An additional measure was the weakening of the structure of the TLTB board, ${ }^{11}$ to which, under the 1997 Constitution, the GCC appointed the majority of members.

It is indeed possible that the Land Use Decree will facilitate land alienation because the LOU, once the lease has expired, may not have the financial capacity required to compensate investors for any general improvement to the land that has occurred during the leasing period. On another issue related to land use, SODELPA argued that the 2010 Surfing Decree did not obligate any investors to compensate the relevant LOU for the use of traditionally owned fishing grounds belonging to Taukei for leisure activities such as surfing, therefore removing potential

9 See clause 15(1) of the 2010 Land Use Decree.

10 See SODELPA 2013.

11 The prime minister becomes board chair and appoints at least three members of the board. 
revenue sources for Taukei landowners. Another general criticism that could be made of the Bainimarama regime's approach with respect to all these policies is that good governance processes, which include public participation and consultation, were not followed.

The controversial land decree, in particular, provided the basis for a political agenda for SODELPA to launch its election campaign against FijiFirst, despite the latter's popularity in many provinces around the country. The party's strategy focused on the need to protect native land and other Taukei institutions in its effort to appeal to Taukei voters, who make up around 58 per cent of the population. Unfortunately, the ethnic approach employed by SODELPA backfired, as many undecided voters from all ethnicities found FijiFirst's liberal manifesto more appealing than SODELPA's conservative approach. For many people it seemed that what mattered was the 'real' development approach taken by the Bainimarama Government for those who needed it mostthe poor, women and children, and rural dwellers. The issue of land insecurity was cushioned by the fact that the Bainimarama campaign seemed to convince many Taukei voters that their land was effectively secured under the 2013 Constitution. In fact, the Land Use Decree was an alternative lease arrangement available for LOUs to utilise unused land, with landowners receiving 100 per cent of the lease revenue.

These policy changes, however, still needed wider national consultations to prevent confusion and possible confrontation amongst landowners. Furthermore, the debate about the Land Use Decree did cause uneasiness amongst many Taukei because of the vague and selective explanations offered by both SODELPA and FijiFirst. The common response from FijiFirst to questions about native land was simply that Taukei land was protected by the Constitution. On the other hand, SOLDELPA emphasised the notion of land alienation and raised the spectre of Taukei becoming landless in their own country. The debate therefore left many Taukei voters confused and feeling that 'we don't know who is telling the truth'. Even so, it is clear that most ultimately placed their trust in FijiFirst.

Part of the problem was that among candidates of both parties there was a lack of understanding about the details of the new land decree, with FijiFirst candidates simply declaring in response to questions that 'Taukei land is safe'. In Wainivula, Suva, a FijiFirst candidate responded abusively when he was questioned by the author about the detailed provisions in the Land Use Decree and the possibility 
that it might lead to a de facto alienation of native land. As a result, this candidate was expelled from representing the party. Two other candidates and current ministers in the then interim government were present but could not answer the questions either. In Nasole, Suva, a FijiFirst candidate could not answer the question regarding a Land Use Decree provision concerning a landowner's right to take the government to court in the event of a dispute. The answer to this question, according to Bainimarama, is that the government may be challenged in court if fewer than 60 per cent of the LOU members consented to allocating the land under the Land Bank (FBC TV 2014).

\section{The 2014 elections results}

Issues concerning land insecurity, which should have been SODELPA's political trump card, appear to have failed to gain much appeal during the 2014 elections, even though the party got the great majority of its votes from among Taukei. For ordinary Taukei, acquiring basic needs and making progress were more important and many believed that their customary land was safe. The 2014 general elections results indicated that voters in many of the 14 provinces of Fiji supported FijiFirst, except for Lomaiviti, Kadavu, Lau and Rewa, which voted predominantly for SODELPA (see Figure 3).

The official result shows 56.5 per cent of the total rural votes went to FijiFirst, with a majority of votes from key provinces such as Ba, $\mathrm{Ra}$, Nadroga-Navosa and Natasiri. These provinces constituted major areas of native leased land for commercial agriculture, tourism, mining and housing. In Ba province alone, the total number of tourism leases on native land by foreign investors is 41 , three times more than other provinces (TLTB 2012, slide 7). More generally, Bainimarama's popularity stretched nationwide, accounting for 202,459 votes. In Yasawa for instance, 29 per cent of the 46 per cent vote for FijiFirst went to Bainimarama personally (see Figure 4). 


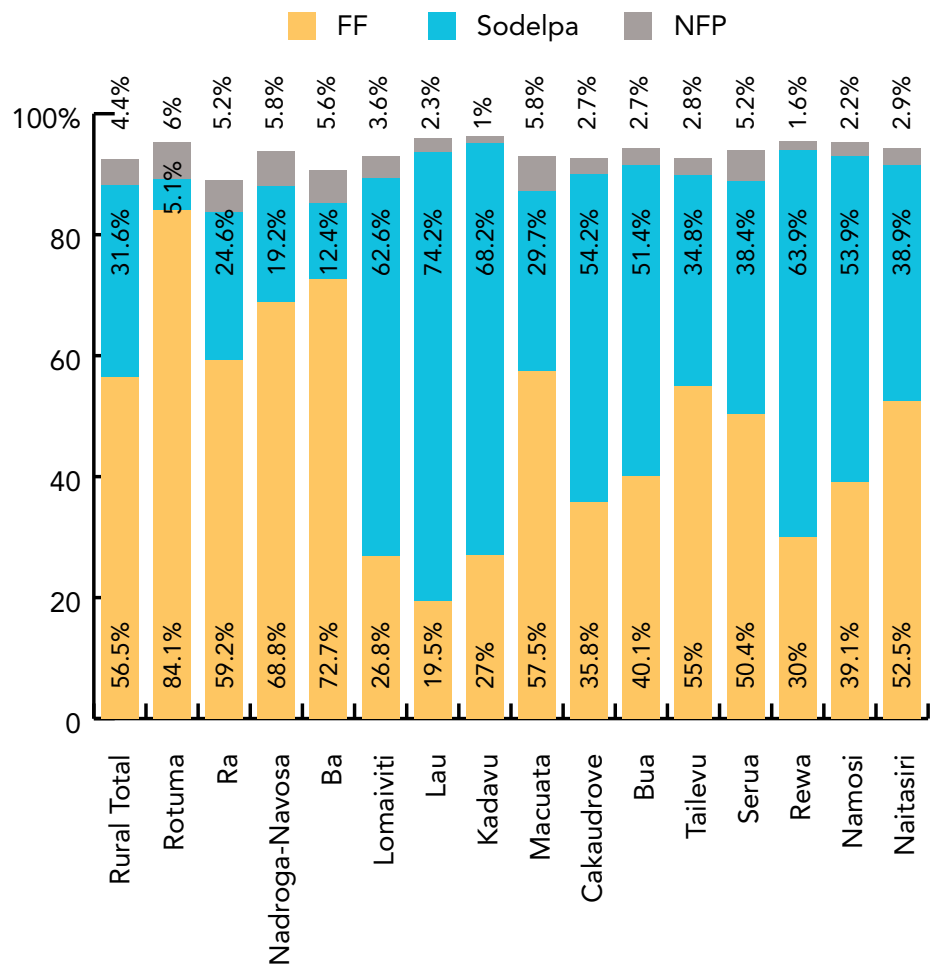

Figure 3: Rural party votes according to province: Fiji 2014 national elections

Source: Nakagawa 2014.

Given these results, it is evident that Taukei voters favoured the changes initiated by Bainimarama for the benefits they appear to have delivered to ordinary LOU members. Ethnic-based voting seemed to have lost its appeal, although whether this remains the case in future voting behaviour remains to be seen. Traditional ties among chiefly families between the provinces remain an important factor in Taukei voting behaviour, as demonstrated in the provinces of Rewa, Cakaudrove and Namosi in 2014. Given that their paramount chiefs were SODELPA candidates, and all won seats in the elections, these provinces remain a stronghold for SODELPA. Lau province, home to some of Fiji's most important statesmen including Fiji's longest-serving prime minster, Ratu Sir Kamisese Mara - a close relative of SODELPA leader Ro Teimumu Kepa - saw some of the highest voting figures for SODELPA (74.2 per cent). 


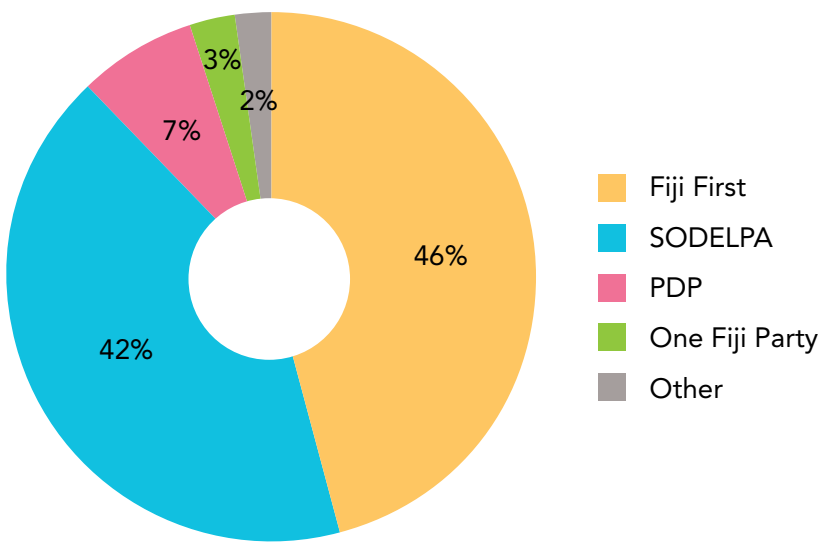

Figure 4: Total votes (\%) in Yasawa by political parties

Source: Nakagawa 2014.

All Fijians will no doubt assess FijiFirst's performance over the next four years, but for Taukei one focus will be on how matters develop in relation to land, especially how the new land use decree is applied. Land is a highly sensitive issue and has the potential to inflame passions and tensions. In its current form, the decree may prove problematic, as it does not provide an avenue for redress of land issues.

\section{Conclusion}

Land issues may have had some impact on the results of the 2014 elections, but the concerns expressed by SODELPA in their campaign were not sufficiently persuasive among Taukei, let alone other communities, to give SODELPA victory in the elections. It seems that Taukei voters, who outnumber all other ethnic groups in terms of voting power, considered other basic matters such as education, water, electricity and other infrastructure as more important than land. In addition, the equal distribution policy gave FijiFirst an advantage, as many LOU members whose lands are leased received economic benefits denied under the old system. In the shorter term, this policy can deliver positive benefits to many more Taukei because it alleviates marginalisation and inequality within the Taukei social structure and potentially can improve the standard of living for all Taukei - rural and urban dwellers alike - if the proceeds are better utilised. It has also contributed to the reduction in the number of 
registered disputes over chiefly titles in the period 2013-14. These improvements may therefore alleviate the perceived insecurities and fear of land alienation that has caused so much political instability in the past. At the same time, perceptions concerning the possibility of future Taukei land alienation need to be clarified. There is also a need to change the current use of newly earned revenue from land from mainly basic consumption to long-term investments to sustain Taukei livelihoods while avoiding land insecurity in the future.

The Land Use Decree offers an alternative lease tenure system for Taukei to develop their land to earn good returns. It encourages innovative land utilisation for the Taukei themselves apart from leasing it to non-Taukei enterprises. It facilitates use of idle Taukei lands for commercial revenue-generating purposes and provides secure access to land to non-Taukei entrepreneurs over a longer period of time. Under this decree, the government also provides technical and financial support for LOUs that allocate their land under the newly created Land Bank to encourage Taukei entrepreneurship. However, the issue of control specifically awarded to the Prime Minister as well as the Minister of Lands within this legislation needs to be rethought to allow LOUs to make their own decisions. This will also help alleviate fears concerning possible alienation.

Finally, what more needs to be done regarding land issues for Taukei in Fiji and their impacts on future general elections? There needs to be wider consultation on the land decrees and policies regarding native land. Awareness about indigenous rights regarding land and innovative commercial programmes to increase productivity benefiting the communities also needs attention and support. The provision of relevant infrastructural and financial support for land development is crucial. The adoption of new methods for commercial ventures for Taukei, such as being core partners in business rather than just being recipients of lease money, needs to be encouraged. By the same token, effective commercial partnerships with non-Taukei entities with business acumen should be sought, built and maintained for the success of any Taukei entrepreneurship; and all such efforts need to be sustained until Taukei can operate independently. Taukei landowners will achieve a greater sense of security once they comprehend the implications of land legislation and feel the tangible benefits flowing from the use of their land. Well-informed Taukei will also not be misguided by fabricated threats frequently used by politicians in 
the past to generate fears about land insecurity. Even so, there may well be ongoing debates regarding traditional social structures and identity, especially with respect to chiefly institutions. The greater equality now enjoyed by Taukei under the new policies may well serve to undermine the traditional social structure and its place in contemporary Taukei society.

\section{References}

Boydell, S 2005, 'Secure land tenure in the South Pacific Region Developing tool kit', in Expert Group Meeting on secure land tenure: 'new legal frameworks and tools', 8-9 December 2005, UNESCAP, Bangkok.

Derrick, RA 1968, A history of Fiji Vol 1, Government Press, Suva.

Dodd, MJK 2012, Reform of leasing regimes for customary land in Fiji. MA thesis, University of Otago, Otago.

FBC (Fiji Broadcasting Commission) 2014, Radio Interview Na Vakekeli Program, 16 July.

FBC TV (Fiji Broadcasting Commission TV) 2014, Straight Talk Program, 8 September.

Fijian Elections Office 2014, 2014 Election Result, Ministry of Information, Suva.

Fiji Electoral Commission 2014, Annual Report, Fiji Electoral Commission, Suva.

Fraenkel, J 2014, 'Reflecting on the 2014 general election', Fiji Times, 22 September.

France, P 1969, The Charter of the Land, Oxford University Press, London.

Gonedua, M 2012, 'Decree abolishes Fiji's GGC', Pacific Island Report, 14 March.

Lal, BV 1988, 'Before the storm: An analysis of the Fiji general election of 1987', Journal of Pacific Studies, vol. 12, no. 1, pp. 71-96. 
Lal, BV 2000, 'Rabuka of Fiji: Coups, constitutions and confusion: Review and Reflections', Review of Rabuka: No Other Way: His Own Story by Eddie Dean \& Stan Ritova; and Rabuka of Fiji: The Authorised Biography of Major-general Sitiveni Rabuka by John Sharpham, The Journal of Pacific History, vol. 35, no. 3, pp. 319-26.

Lawson, S 1996, Tradition versus democracy in the South Pacific, Cambridge University Press, Oxford.

Madraiwiwi, J 2014, 'Analysis: where parties going?', Fiji Sun [Online] 28 August. Viewed 7 January 2015 at fijisun.com.fj/2014/03/31/ ratu-joni-madraiwiwi-analysis-where-parties-going/.

Nabobo, U, Baba, T and Anai, M 2005, Pacific Education; Issues \& Perspectives, University of the South Pacific, Suva.

Nakagawa, H 2014, 'Analysis of Fiji's general election 2014 by region and urban/rural division', School of Government, Development and International Affairs Writers' Workshop on the 2014 General Election, 22 November 2014, University of the South Pacific.

Narsey, W 2008, The quantitative analysis of poverty in Fiji, Vanuavou Publications, Suva.

Nayacakalou, RR 1975, Leadership in Fiji, Institute of Pacific Studies, University of the South Pacific, Suva.

NFP (National Federation Party) 2014, Our People's Future Manifesto 2014 General Elections, NFP Suva.

Ravuvu, A 1998, Development or dependence, Institute of Pacific Studies, University of the South Pacific, Suva.

Sakai, S 2014, 'National governance on native land its impact on the livelihood of the iTaukei', in Pacific Island Political Studies Association Conference, 3-7 July, University of French Polynesia, Tahiti.

Scarr, D 1999, 'Communalism and a Constitution: Fiji's General Election of 1999', Journal of Pacific History, vol. 34, no. 3, pp. 253-58.

SODELPA 2013, A new type of Land Alienation? Indigenous Fijian Land and Government Constitution', media release No. 10/2013 (August). 
TLTB (iTaukei Land Trust Board) 2012, Presentation to the Executive Management Board. Unpublished, 20 December, TLTB Boardroom, Nadi.

TLTB (iTaukei Land Trust Board) 2014, 'TLTB's achievement 20082014', Na I Rogo, vol. 3, no. 3, pp. 1-12.

Tupouniua, S, Crocombe, R and Slatter C (eds) 1980, The Pacific Way, South Pacific Social Sciences Association, Suva.

Tuwere, I 2002, Vanua: Towards a Fijian theology of place, Institute of Pacific Studies and College of St John the Evangelist, Suva.

Vakacolo, S 2014, 'Majority want to know more about our land', Fiji Times. 30 August. 
This text is taken from The People Have Spoken: The 2014 Elections in Fiji, edited by Steven Ratuva and Stephanie Lawson, published 2016 by ANU Press, The Australian National University, Canberra, Australia. 